v. $13, n .4$

Vitória-ES, Jul.-Aug. 2016

p. $94-117 \quad$ ISSN 1808-2386 DOI: http://dx.doi.org/10.15728/bbr.2016.13.4.5

\title{
The Moderating Effect of Home Country Corruption on the Host Country's Ability to Attract FDI
}

\author{
Manuel Portugal Ferreira ${ }^{\dagger}$ \\ Nove de Julho University - UNINOVE / Polytechnic Institute of Leiria - ESTG
}

\author{
Helder Costa Carreira ${ }^{\Omega}$ \\ Polytechnic Institute of Leiria - ESTG \\ $\operatorname{Dan} \mathbf{L i}^{¥}$ \\ Kelley School of Business - IU \\ Fernando Ribeiro Serra ${ }^{ \pm}$ \\ Nove de Julho University - UNINOVE
}

\begin{abstract}
Prior research has identified a negative impact of corruption on countries' ability to attract Foreign Direct Investment (FDI) but has been scant in assessing the investors' home country effects. We extend prior research by distinguishing the pervasiveness and arbitrariness of host country corruption and their effects on FDI inflows. We also test whether the investors' home country corruption affects FDI decisions. Results show that host country pervasive corruption negatively drives FDI inflows but not the arbitrariness component. While the investors' home country corruption negatively impacts the overall FDI outflows, investors from countries with high levels of corruption do not seem to be deterred by a high level of pervasive corruption in the host country. These results suggest that there may exist some form of corruption-dealing capability whereby firms from countries with high corruption are less sensitive to host country corruption and in fact they are able to leverage their capability and invest more in corrupt hosts.
\end{abstract}

Keywords: Corruption effects. Home country corruption. Corruption-dealing capability.

Received on 03/03/2015; Reviewed on 05/13/2015;Accepted on 08/28/2015; Divulgued on 07/04/2016.

\footnotetext{
*Author for correspondence:

†. PhD Business Administration.

Link: Strategy Professor of the

PPGA(Graduate Program in

Business Administration) at the

Nove de Julho University \& at

ESTG - Polytechnical Institute of

Leiria.

Address: Avenue Francisco

Matarazzo, 612, Prédio C $-2^{\circ}$, São

Paulo - SP - Brazil. Cep. 05001-

100.

E-mail:

manuel.portugal.ferreira@gmail.com

$\Omega$ Master in Internationa ness.

Link: ESTG -Polytechnic Institute of Leiria \& globADVANTAGE -

Center of Research in International Business \& Strategy.

Address: Morro do Lena, Alto Vieiro - Leiria -

Portugal. PBox 2411-901.

E-mail:

h.costacarreira@gmail.com
}

$¥$ PhD in Management.
Link: Kelley School of
Business, Indiana
University.
Address: Kelley School of
Business - IU.
Bloomington - IN - USA.
PBox 47405-1701.
E-mail: lid@indiana.edu

\author{
\pm Doctor of Engineering, \\ Post-Doctorate in \\ Administration. \\ Link: PPGA Nove de \\ Julho Universtity \& \\ globADVANTAGE - \\ Center of Research in \\ International Business \& \\ Strategy. \\ Address: Avenue \\ Francisco Matarazzo, 612, \\ Prédio $\mathrm{C}-2^{\circ}$, São Paulo - \\ SP - Brazil. Cep. 05001- \\ 100. \\ E-mail: \\ fernandorserra@gmail.com
}




\section{INTRODUCTION}

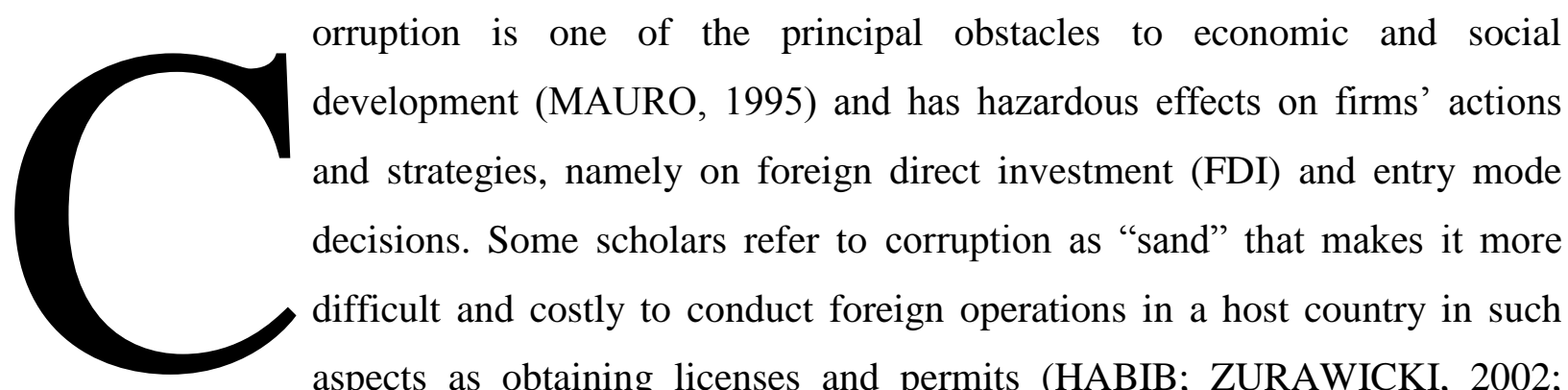
aspects as obtaining licenses and permits (HABIB; ZURAWICKI, 2002; VOYER; BEAMISH, 2004; CUERVO-CAZURRA, 2006, 2008). Other studies, however, point that host country corruption may hold a positive impact on FDI, acting as "grease" (LEFF, 1964; HUNTINGTON, 1968; BARDHAN, 1997; EGGER; WINNER, 2005; CUERVO-CAZURRA, 2008; AIDT, 2009) by expediting exchanges and allowing private firms to overcome ineffective regulations and governmental institutions. Yet others examine the impact of FDI on corruption (KWOK; TADESSE, 2006). There is also research reporting that corruption exerts no impact on the FDI inflow (WHEELER; MODY, 1992). The empirical, and even the conceptual, evidence is thus rather inconclusive on the effects of corruption on FDI. Moreover, only a few studies have delved into the possible effect that the home country of the investor firms may have (MCWILLIAMS et al., 2002; HILLMAN et al., 2004; HOLTBRÜGGE, 2007, JIMÉNEZ; DELGADO, 2012).

The institutional quality of countries is a core determinant of their ability to attract FDI (WERNICK; HAAR; SINGH, 2009). Particularly relevant are the formal institutions because they provide the environmental background on which transactions and businesses take place and corruption signals the failure of those norms and regulations governing transactions. Consequently, countries with high levels of corruption are likely to show poor performance in attracting FDI (WEI, 1998). However, it is possible that firms use those institutional insufficiencies, and specifically corruption, proactively in their internationalization strategies (JIMÉNEZ, 2010). That is, firms may deploy home-based developed political capabilities (e.g., HILLMAN et al., 2004; HOLTBRÜGGE et al., 2007) when entering countries with high levels of corruption. In such instances, it is possible that firms from corrupt countries may develop an ability to deal with high corruption in their internationalization.

In this paper, we propose, complementing extant literature on how corruption impacts FDI flows, to consider both host and home country effects, specifically examining the moderating role of home country corruption on the relationship between the host country corruption and FDI received. Moreover, these effects may be better captured using, for 
instance, the well-known distinction between the pervasiveness and arbitrariness of host country corruption. Our empirical tests were based on FDI from 28 OECD home countries into 49 host countries, a sample of 875 pairs of FDI home-host countries, and employ a nonlinear Tobit model. We found that the host country pervasive corruption negatively impacts the FDI inflows, but we failed to find a significant effect of arbitrary corruption. We also found support for the significant effect of high levels of corruption in the home countries in undertaking FDI in a host country and the interactive effect of home and host countries' corruption on the FDI flows, such that corruption in the home and host countries increases FDI. Hence, the investors' home country corruption is shown to be a significant predictor of FDI flows, an aspect that has been largely often overlooked in prior research.

This study contributes to better understand the effect of corruption of FDI, following the extant literature (WEI, 1998; HABIB; ZURAWICKI, 2002; CUERVO-CAZURRA, 2006, 2008; JUDGE et al., 2011). Perhaps its contribution is more salient to promote the debate on how firms may develop political capabilities, and especially the ability to deal with corruption in the host countries, in their internationalization (see HILLMAN et al., 1999; HOLTBRÜGGE et al., 2007; JIMÉNEZ; DELGADO, 2012). To some extent we have partial evidence that the investors' home country corruption does seem to matter, sustaining the argument that firms may be able to develop a home grown corruption-dealing capability. In a similar vein, it is possible that the value of using these capabilities, which we may conceptualize in a broader manner to encapsulate dealing with other institutional insufficiencies, is also a function of the countries to which firms seek to expand to.

In the following sections, we briefly review the relevant literature on corruption and its impact on FDI, and then advance hypotheses concerning how corruption in the home and host country is likely to drive FDI. The third section comprises the methodology, including sample and variables. Section four is devoted to the results. We conclude with a broad discussion, pointing out limitations and avenues for future inquiry.

\section{LITERATURE REVIEW}

The World Bank (2000) defines corruption as the abuse of power to obtain private benefits and includes payments of bribes, favoritisms, inappropriate use of influences, irregular payments in public contracting. The last decade has seen an upsurge in scholarly attention to the effects of corruption on various aspects of economic activities. Mostly this research delves into the hazardous effects of corruption, either on economic growth and development (e.g., SHLEIFER; VISHNY, 1993; MAURO, 1995, 1998), productivity and 
foreign investment (e.g., MAURO, 1995; DOH et al., 2003; LAMBSDORFF, 2003), or with firms strategies in corrupt environments (JENSEN et al., 2010; SPENCER; GOMEZ, 2011; KARHUNEN; LEDYAEVA, 2012; BARBOPOULOS et al., 2014). A sizeable portion of these studies focus on corruption and a country's ability to attract foreign direct investments.

Transaction costs and institutional theory approaches are two conceptual angles prior researchers have adopted to explore and better understand the effects of corruption (SHLEIFER; VISHNY, 1993; MAURO, 1998; UHLENBRUCK et al., 2006). Several studies relate corruption to the added costs of doing business in highly corrupt countries (CUERVOCAZURRA, 2006, 2008). Other studies relate corruption with the institutional development of a country (DOH et al., 2003; UHLENBRUCK et al., 2006) or firms' exports (LEE; WENG, 2013). According to North (1990), institutions provide the foundations, or playing field, that individuals use to reduce uncertainties that may arise in their transactions. The transaction costs are likely higher in less institutionalized countries (DELIOS; HENISZ, 2003; HENISZ, 2000). Because institutions provide the structure where transactions take place, the institutional quality is an important determinant of FDI (KINOSHITA; CAMPOS, 2004; ZEGHNI; FABRY, 2009). Corruption increases market imperfections (WILLIAMSON, 1985) and heightens transaction costs (DELIOS; HENISZ, 2000).

The relevance of institutional factors on the ability to attract FDI has been examined extensively. Corruption, at least in some of its manifestations, may be the outcome of institutional insufficiencies. Busse and Hefeker (2007) examined the linkages between political risk, institutions and FDI flows among developing economies and concluded that government stability, social conflicts and ethnic tension, law and order and corruption determine the flows of FDI (BÉNASSY-QUÉRÉ et al., 2007). Daude and Stein (2007) reported that the greater the country's institutional quality the higher its ability to attract FDI and that unpredictability, excessive regulation and political instability hinder foreign investment.

The institutional environment influences FDI flows in varied manners. Daniele and Marani (2006) noted that institutional quality reduces the investment costs and bears an impact on FDI. Notwithstanding the extant research, the empirical evidence on the impact of corruption on FDI is inconclusive. The relationship between a host country's corruption and the FDI it receives has usually been found to be negative (e.g., WEI, 2000; LAMBSDORFF, 2003; VOYER; BEAMISH, 2004), but some studies do not find any relation (e.g., WHEELER; MODY, 1992; HENISZ, 2000). The dominant stream argues for a negative 
impact of corruption on countries' ability to attract FDI, noting that corruption heightens costs of undertaking FDI in high-corruption countries and view corruption as a deterrent to FDI inflow (CUERVO-CAZURRA, 2008). Similar research includes Abed and Davoodi (2000) uncovering that lower levels of corruption in transition economies were related to the attraction of more foreign investors, and Habib and Zurawicki (2002) reporting that foreign investors avoid corrupt locations for moral reasons and operational risks.

Other stream, conversely, noted that corruption could act as "grease" (LEFF, 1964; CUERVO-CAZURRA, 2006) especially in those countries where institutions are weak or have not been fully established, and regulation is either excessive or ineffective. In these instances, corruption may expedite transactions by overcoming the institutional deficiencies (BARDHAN, 1997). This approach gained some momentum with the publications of Nathan Leff's (1964) articles on "Economic development through bureaucratic corruption". The rationale for a positive impact of corruption is that corruption may contribute to eliminate excess bureaucracy (HUNTINGTON, 1968). More recently Egger and Winner (2005) used data from 73 countries to conclude that corruption is a stimulus to FDI.

\section{CONCEPTUAL DEVELOPMENT}

Figure 1 summarizes the hypotheses drawn, examining how corruption impacts on the FDI flows, taking two complementary views to the extant research: (1) the distinction between host country arbitrary and pervasive corruption, and (2) the moderating effect of home country corruption.

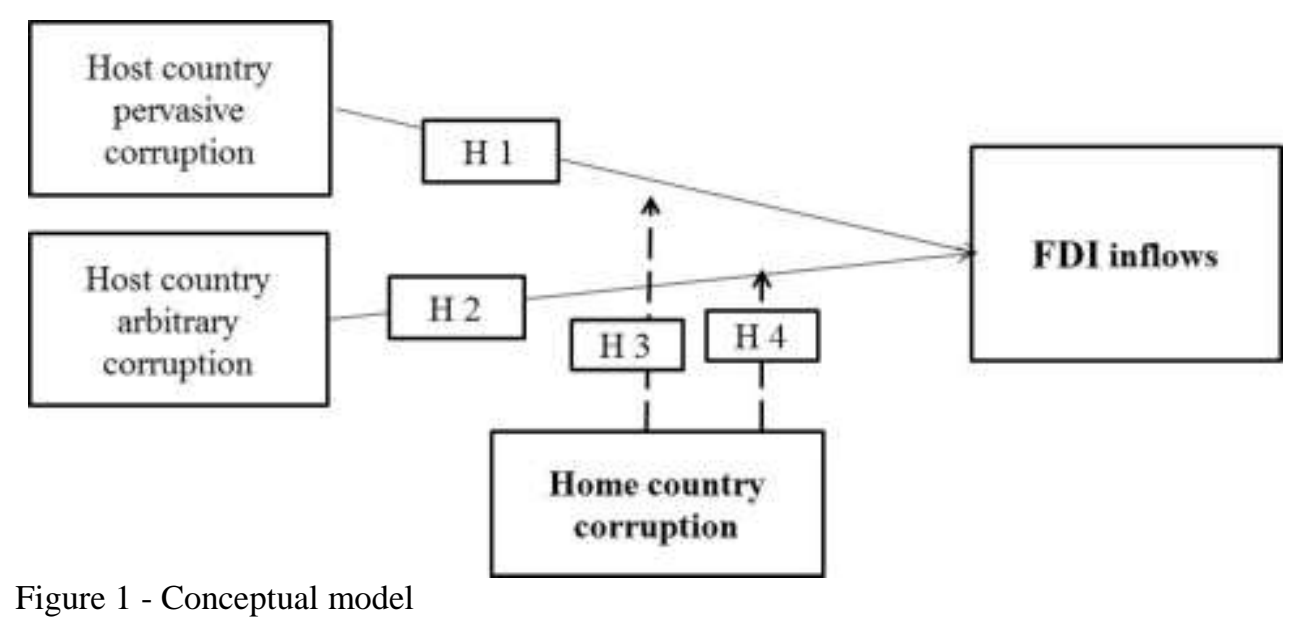

\subsection{HOST COUNTRY PERVASIVE CORRUPTION AND FDI INFLOWS}

Corruption has a negative impact on several facets of the economic environment, from the quality of the infrastructures and the efficiency of the public sector and public investment (TANZI; DAVOODI, 1997) to inequalities in the distribution of income (XU; LI; ZOU, 
2000). Broadly put, in corrupt countries investors incur in the added costs of bribing, obtaining information, authorizations, permits and protection (CUERVO-CAZURRA, 2006). Shleifer and Vishny (1993) and Wei (2000), for example, refer that corruption works as an additional tax, which in some instances may be highly variable (ROSE-ACKERMAN, 1999).

However, there are different forms of corruption. A widely used distinction contrasts pervasive and arbitrary corruption and often argues that pervasive or "organized" corruption and arbitrary or "disorganized" corruption influence FDI flows through different venues (SHLEIFER; VISHNY, 1993; MAURO, 1998; HERRERA; RODRIGUEZ, 2003). Pervasive corruption reflects the degree to which corruption is generalized in the public sector. Pervasive corruption is widespread across all departments and is absolutely institutionalized (RODRIGUEZ; UHLENBRUCK; EDEN, 2005). Collins and Uhlenbruck's (2004) work showed that when managers observe corruption they tend to get involved in corrupt "schemas". That is, in pervasive corruption environments firms will be more prone to get involved in corrupt practices.

In countries with high pervasive corruption investors may estimate the added costs of doing business (CUERVO-CAZURRA, 2008). In these countries firms are already expecting invitations for bribes and irregular payments to get what they need or want, from documentation to contracts. These actions increase the costs of operating (MEYER, 2001). Thus, it is reasonable to suggest that foreign investors retract from undertaking FDI operations in countries with greater levels of pervasive corruption due to the added costs that may render the operations unviable, even considering the predictability of these costs.

Hypothesis 1. Host countries with higher levels of pervasive corruption tend to receive less FDI inflows.

\subsection{HOST COUNTRY ARBITRARY CORRUPTION AND FDI INFLOWS}

Several authors argue that the impact of arbitrary corruption may be superior to that of pervasive corruption (AHLSTROM; BRUTON, 2001; RODRIGUEZ et al., 2005; CUERVOCAZURRA, 2006). Arbitrary corruption refers to the uncertainty or ambiguity associated to corrupt transactions in the country (RODRIGUEZ et al., 2005; CUERVO-CAZURRA, 2008). Wei (1997) noted that the uncertainties associated to corruption may be more damaging for FDI than the actual level of corruption installed. Rodriguez et al. (2005) argued that arbitrarity reduces firms' ability to fulfill the requirements of governmental regulations. If corruption arbitrariness is low, the payments to corrupt officials are like a fixed tax (WEI, 1998, 2000) that predictably should not affect, at least not substantially, managers' decisions because they 
are already expecting it. In contrast, when corruption is more arbitrary, firms have to negotiate and are subject to discretionarity, namely that accruing from differing interpretations of laws and regulations by government officials (AHLSTROM; BRUTON, 2001; RODRIGUEZ et al., 2005). In these instances, uncertainty is higher and the costs of corruption may be greater as each official varies the requirements to profit the most.

Shleifer and Vishny (1993) refer to arbitrary corruption as "disorganized corruption" where different officials solicit bribes and payments, independently from each other. As a result, bribing one official does not preempt others from jumping in and soliciting again. The lack of "coordination", or "organization", and the impossibility of even then guaranteeing the operations substantially increase the costs and renders planning a futile exercise. In fact, Shleifer and Vishny (1993) further suggest that in regimes of organized corruption the costs may be smaller and the hazardous effects of corruption may be less significant than when corruption is disorganized, or arbitrary. Independently of which type of corruption bears the largest impact, we hypothesize that:

Hypothesis 2. Host countries with higher levels of arbitrary corruption tend to receive less FDI inflows.

\subsection{CORRUPTION IN THE HOME COUNTRY}

Although much of the foreign investment flow originates in the more developed economies with lower levels of corruption, during the past two decades there has been an increase in the FDI from emerging economies, and presumably more corrupt countries. It seems reasonable to suggest that firms that operate in corrupt home countries develop an "ability" to deal with corruption. For these firms bribing and irregular payments are part of the usual business operations and as such they are aware of how to corrupt, offer bribes and get things done - and they may even get good at it (CUERVO-CAZURRA, 2008). Managers are able to use this capability when internationalizing and facing similar corrupt requests. This corruption capability entails a mindset whereby managers alter their business assumptions to include corruption as a legitimate and required operation, the negotiation process and the identification of what is the best manner to go with it. Perhaps, managers will be more prone to invest in host countries that are similar to their home country in this respect (see CUERVOCAZURRA, 2006). For these firms, host country corruption per se may not be seen as a problem and in fact it may give them an advantage vis a vis firms from countries with low levels of corruption. 
Firms internationalize first to countries that are similar to their home environments (JOHANSON; VAHLNE, 1977) which can be extended to include institutional environment, more specifically, levels of corruption. These countries are closer in psychic distance and raise less uncertainty. We argue that firms from highly corrupt countries may deploy their experienced managers to take charge of the operations in corrupt host environments (CUERVO-CAZURRA, 2006), and that investors from highly corrupt countries will tend to search and enter other equally corrupt countries. The level of corruption of the home country may thus be hypothesized to influence on how sensitive FDI will be to host country corruption. The following hypotheses relate to the moderating effects of the home country corruption.

Hypothesis 3. The negative relationship between pervasive corruption in the host country and FDI inflows is weakened when the investors' home countries have high levels of corruption.

Hypothesis 4. The negative relationship between arbitrary corruption in the host country and FDI inflows is weakened when the investors' home countries have high levels of corruption.

\section{METHOD}

\subsection{SAMPLE}

Our sample consists of 875 pairs of FDI home and host countries; there are 28 home countries $^{1}$ and 49 host countries ${ }^{2}$ in 2008 . The home countries are members of the OECD for which FDI data was available from the OECD website.

\subsection{MEASURES}

The dependent variable is a host country's FDI inflow conducted by a specific home country. The natural logarithm format of the FDI inflow volume measured in millions of USD is used in the regression analysis. We did two additional procedures: first, we coded as zero de negative flows, second, to not eliminate zero FDI flow cases we added one to the log of FDI.

\subsubsection{Independent variables}

Host country pervasive corruption. Pervasive corruption assesses the likelihood a firm will be demanded with extra payments and bribes whenever they deal with the government, courts and judges. We measured corruption in the host country using the corruption perception index (CPI) by Transparency International (see also CUERVO-CAZURRA, 2007). 
The CPI index ranges from 0 (high level of corruption) to 10 (low level of corruption), we inverted the scores so that a higher score signifies higher levels of corruption. Other scholars used alternative measurements. For instance, Uhlenbruck et al. (2006) and Bogmans and Jong (2011), used data from the World Business Environment Survey (2008). We tested this alternative and found a correlation of 0.949 with the CPI measurement.

Host country arbitrary corruption. Arbitrary corruption reflects the degree of ambiguity/uncertainty associated to corrupt transactions in a given country. This variable is measured by the standard deviation of the CPI, or stated differently of the individual executive responses related to corruption in the CPI. The variance reflects the uncertainty over the widespread of corruption and the larger the standard deviation, the greater the different perceptions among the interviewees, which is a proxy for arbitrariness (see BOGMANS; JONG, 2011).

Home country with high corruption. We used the CPI index, inverting the scores as explained above, to capture the home country corruption. Moreover, we dichotomized the variable - high versus low level of corruption - such that a home country was deemed to have high corruption if its CPI was above the average of the 28 home countries. Thus, the variable home country with high corruption takes the value of 1 when the home country's CPI index is greater than 3.05 and 0 when it is less than 3.05.

\subsubsection{Control variables}

A set of control variables was included in the regression analysis to account for possible alternative explanations. Gravitational models explain FDI using indicators of host country size (GDP or population) and the geographic distance between home and host countries (LINNEMAN, 1966). This model has been adopted in prior studies on the effects of corruption on FDI inflows (WEI, 2000; BEVAN; ESTRIN, 2004; CUERVO-CAZURRA, 2007).

Host country size. Larger countries are likely to attract more FDI inflow because they have larger consumer markets and investing firms can exploit scale economies (LINNEMAN, 1966; WEI, 2002). The measurement is the natural logarithm of the number of inhabitants of the host country, using data collected from the World Development Indicators, of the World Bank (2009). Such a measure has been used in prior studies (BEVAN; ESTRIN, 2004; BOGMANS; JONG, 2011). 
Home-host distance. Distance reflects transportation costs that hinder trade and favor FDI (LINNEMAN, 1966; WEI, 2000). We employ two variables to capture the physical distance between a pair of home-host countries. First, we adopt the CEPII ${ }^{3}$ distance which measures the metric distance between the countries capital cities (WEI, 2000B; CUERVOCAZURRA, 2008; BOGMANS; JONG, 2011). Second, geographic distance is often complemented with other measurements such as whether the country is coastal, in which case transportation costs in international trade may decrease due to the use of maritime means and leads firms to prefer exporting over FDI operations (FRANKEL; ROSE, 2002). The coastal information is retrieved from the CEPII database. The variable coastal country equals to 0 if neither the home or host country is coastal, 1 if one of the pair is coastal and 2 if both are coastal (WEI, 2000B; CUERVO-CAZURRA, 2007; BOGMANS; JONG, 2011).

Host country restrictions to FDI. Restrictions to FDI are likely to have a negative impact on FDI inflows. We measured FDI restrictions using data from the Global Competitiveness Report 2008-2009, specifically the item with a 7-point likert scale: "To what extent do rules governing foreign direct investment (FDI) encourage or discourage it?" The scaling was inverted so that a higher value denoted larger restrictions. By controlling for FDI restrictions we account for the explanation that FDI inflows may be influenced not by corruption but instead by the existing restrictions.

Host country trade restrictions. International trade restrictions may lead firms to prefer entering a country with FDI operations, serving the host market with local production rather than imports (e.g., WEI, 2000B; CUERVO-CAZURRA, 2007; BOGMANS; JONG, 2011). High tariff barriers may lead firms to undertake FDI as a substitute for exports (GROSSE; TREVINO, 1996). This variable was measured using the freedom of trade index of the economic freedom indicator of the Heritage Foundation.

Host country inflation. The inflation rate is an indicator of macroeconomic stability useful to assess the uncertainty of carrying out operations in those countries. High inflation rates heighten uncertainty and risk and the costs of monitoring, financing and control. This variable was measured by the percentage increase of consumer prices using data from the World Development Indicators (WEI, 2000B; CUERVO-CAZURRA, 2007; BOGMANS; JONG, 2011).

Host country bureaucracy. Bureaucracy, typically referred to as red tape, exerts excessive procedures for businesses and reduces the attractiveness of the country as a recipient of foreign investment. In fact, the study International Business Report (IBR) 2011 
by Grant Thornton concluded that excessive bureaucracy is the main limiting factor of Brazilian firms' ability to grow. We used the proxy of the number of days to start a business to measure host country bureaucracy (KINOSHITA; CAMPOS, 2004; BÉNASSY-QUÉRÉ ET AL., 2007). Data were retrieved from the Global Competitiveness Report 2008-2009. By controlling for the level of bureaucracy we exclude the explanation that FDI inflows may be decreased not due to corruption but rather by excessive and costly bureaucracy.

Table 1 offers a summary description of all variables and data sources used.

\begin{tabular}{|c|c|c|c|}
\hline \multicolumn{2}{|c|}{ Variable } & \multirow{2}{*}{$\begin{array}{l}\text { Description } \\
\text { Natural log of the FDI inflows in } 2008 \text { into } \\
\text { a host country, in millions of USD }\end{array}$} & \multirow{2}{*}{$\begin{array}{r}\text { Source } \\
\text { OECD }\end{array}$} \\
\hline $\begin{array}{l}\text { Dependent } \\
\text { variable }\end{array}$ & FDI inflows (Ln) & & \\
\hline \multirow[t]{3}{*}{$\begin{array}{l}\text { Independent } \\
\text { variables }\end{array}$} & $\begin{array}{l}\text { Home country } \\
\text { with high } \\
\text { corruption }\end{array}$ & $\begin{array}{l}\text { Dummy indicator of whether the level of } \\
\text { corruption is above (1) or below ( } 0) \text { the } \\
\text { average ( } 3.05 \text { ) for all home countries. The } \\
\text { measure of corruption is the CPI - } \\
\text { Corruption Perception Index. }\end{array}$ & $\begin{array}{l}\text { Transparency } \\
\text { international (2008) }\end{array}$ \\
\hline & $\begin{array}{l}\text { Host country } \\
\text { pervasive } \\
\text { corruption }\end{array}$ & $\begin{array}{l}\text { The measure of corruption is the CPI - } \\
\text { Corruption Perception Index. }\end{array}$ & $\begin{array}{l}\text { Transparency } \\
\text { international (2008) }\end{array}$ \\
\hline & $\begin{array}{l}\text { Host country } \\
\text { arbitrary } \\
\text { corruption }\end{array}$ & Standard deviation of the CPI. & $\begin{array}{l}\text { Transparency } \\
\text { international (2008) }\end{array}$ \\
\hline \multirow[t]{7}{*}{$\begin{array}{l}\text { Control } \\
\text { variables }\end{array}$} & Host country size & $\begin{array}{l}\text { Natural log of the number of inhabitants in } \\
\text { the country. }\end{array}$ & $\begin{array}{l}\text { World Bank } \\
\text { Development } \\
\text { indicators (2009) }\end{array}$ \\
\hline & $\begin{array}{l}\text { Home-host } \\
\text { distance }\end{array}$ & $\begin{array}{l}\text { Natural log of the distance in kilometers } \\
\text { between a pair of country capital cities } \\
\text { (home and host) - greater distance circle. }\end{array}$ & $\begin{array}{l}\text { CEPII } \\
\text { http://www.cepii.fr/ } \\
\text { anglaisgraph/bdd/di } \\
\text { stances.htm }\end{array}$ \\
\hline & Coastal country & $\begin{array}{l}\text { Indicator of a maritime frontier of host and } \\
\text { home country: none }(0) \text {, one country (1) } \\
\text { and both countries }(2)\end{array}$ & CEPII \\
\hline & $\begin{array}{l}\text { Host country } \\
\text { restrictions to FDI }\end{array}$ & $\begin{array}{l}\text { Assesses the restrictions raised on foreign } \\
\text { investment. Based on one item: "To what } \\
\text { extent do rules governing foreign direct } \\
\text { investment (FDI) encourage or discourage } \\
\text { it?", from (1) strongly discourage FDI to } \\
\text { (7) strongly encourage FDI }\end{array}$ & $\begin{array}{l}\text { Global } \\
\text { competitiveness } \\
\text { report: 2008-2009 }\end{array}$ \\
\hline & $\begin{array}{l}\text { Host country } \\
\text { trade restrictions }\end{array}$ & $\begin{array}{l}\text { This index assesses international trade } \\
\text { restrictions. Varies between } 100 \text { - very } \\
\text { low restrictions on trade and } 0 \text { - very high } \\
\text { restrictions on trade. }\end{array}$ & $\begin{array}{l}\text { Heritage } \\
\text { Foundation } 2009\end{array}$ \\
\hline & $\begin{array}{l}\text { Host country } \\
\text { inflation }\end{array}$ & $\begin{array}{l}\text { Percentage increase of the consumer } \\
\text { prices. }\end{array}$ & $\begin{array}{l}\text { World Bank } \\
\text { Development } \\
\text { indicators } 2008\end{array}$ \\
\hline & $\begin{array}{l}\text { Host country } \\
\text { bureaucracy }\end{array}$ & $\begin{array}{l}\text { Assesses bureaucracy in a host country } \\
\text { proxied by the number of days to start a } \\
\text { business. }\end{array}$ & $\begin{array}{l}\text { Global } \\
\text { competitiveness } \\
\text { report: } 2008-2009\end{array}$ \\
\hline
\end{tabular}

Table 1 - Variables, measurement and data sources

\subsection{PROCEDURE}

The model specification follows Wei (2000a) and Cuervo-Cazurra (2006). Since we have logged variables on both sides of the equation, namely FDI, population and distance, this 
specification is termed as a double-log model (WEI, 2000a). We considered a one-year time lag between the dependent and independent variables to account for the time needed between managers' environment analysis and the actual FDI activities (see, for example, CUERVOCAZURRA, 2006). To correct for heteroskedasticity hazards we calculated robust standard deviations, adapting Wei's (2000) modeling. We used a Tobit specification since the dependent variable assumes non negative values (see also CUERVO-CAZURRA, 2008), and the log of FDI plus one, since in some instances FDI may be zero.

\section{RESULTS}

Table 2 (Appendix) displays the sample descriptive statistics and correlations. To test whether a problem of multicollinearity exists in our estimation, we followed the approach recommended by Neter, Kutner, Nachtsheim and Wasserman (1996) and computed variance inflation factors (VIFs) are computed when all variables were included in each model. We further checked variance inflation factors (VIF) that were within acceptable ranges denoting that multicollinearity does not impose damage to our estimation.

Table 3 summarizes the regression analysis. Model 1 includes only the control variables. Model 2 tests Hypotheses 1 and 2, including the impact of two facets of corruption - pervasive and arbitrary - on the inflows of FDI. The coefficient on pervasive corruption is negative and statistically significant ( $\mathrm{p}<0.05)$, meaning that pervasive corruption negatively influences FDI inflows. This result supports Hypothesis 1. However, the coefficient for arbitrary corruption is not statistically significant and we failed to find empirical support for $\mathrm{H} 2$.

Model 3 includes the interaction terms to test Hypotheses 3 and 4 on the interaction of home country high level of corruption with the two dimensions of host country corruption. Testing H3, the coefficient of the interaction was positive and statistically significant $(\mathrm{p}<0.05)$, evidencing that in comparison with investors from countries with low levels of corruption, investors from countries with high levels of corruption are less sensitive to the pervasiveness of corruption in the host country. That is, the negative effect of host country pervasive corruption on FDI is alleviated when the investors are from countries with high corruption. Hence, Hypothesis 3 was confirmed. However, the interaction term on the arbitrary corruption is not statistically significant, and thus no empirical support for Hypothesis 4 was found. 
Table 3 - Regression Results

\begin{tabular}{|c|c|c|c|}
\hline & Model 1 & Model 2 & Model 3 \\
\hline Host country pervasive corruption & --- & $-0.230 * * *$ & $-0.305 * * *$ \\
\hline Host country arbitrary corruption & -- & 0.041 & -0.183 \\
\hline Home country with high corruption & - & - & $-3.768 * * *$ \\
\hline $\begin{array}{l}\text { Home country with high corruption } * \text { Host } \\
\text { country pervasive corruption }\end{array}$ & -- & -- & $0.212 * * *$ \\
\hline $\begin{array}{l}\text { Home country with high corruption * Host } \\
\text { country arbitrary corruption }\end{array}$ & -- & -- & 0.410 \\
\hline Home-host distance & $-0.151 * * *$ & -0.071 & $-0.104 * *$ \\
\hline Host country size (Pop. Ln) & $0.536 * * *$ & $0.613 * * *$ & $0.579 * * *$ \\
\hline Coastal country & -0.223 & -0.274 & $-0.292 *$ \\
\hline Host country restrictions to FDI & $-0.517 * * *$ & $-0.389^{*}$ & $-0.332 *$ \\
\hline Host country trade restrictions & 0.003 & -0.004 & -0.001 \\
\hline Host country bureaucracy & 0.002 & 0.009 & 0.011 \\
\hline Host country inflation & $-0.050 * *$ & -0.024 & -0.016 \\
\hline Intercept & -2.459 & -3.135 & -1.152 \\
\hline $\mathrm{Chi}^{2}$ & 112.4527 & 122.004 & 378.670 \\
\hline $\mathrm{N}$ & 875 & 875 & 875 \\
\hline Log likelihood & -2051.803 & -2046.656 & -1940.203 \\
\hline
\end{tabular}

\subsection{ROBUSTNESS TESTS}

To conclude we conducted additional analyses to see how robust were the results on the effect of corruption. We first, checked whether the effects could be driven by transition or emerging economies. The statistical results failed to present evidence that such effect did exist. Specifically, given the institutional inefficiencies, and since these countries have been posited to have high levels of arbitrary corruption, in addition to pervasive, we checked whether the FDI into these countries revealed a different pattern than investments to other, institutionally more developed, locations. Both subgroup analyses and entering these countries as moderators did not present statistically significant evidence of such effect. Another set of sensitivity analyses entailed considering additional measures of economic development and size. Measuring host country size by the GDP in log form, instead of population, the results remained similar. We also took into account the level of development of both home and host country. We followed the 2007 World Bank Analytical Classifications and created a dummy variable taking the value of 1 for high income and upper middle income countries, and 0 otherwise. All investor countries are high income, and the regression results showed robust to this additional test. Finally, we controlled for whether the host country is an 
oil producer with data collected from the US Energy Information Administration (www.eia.gov) and again there was no change in the significances of the hypotheses tested.

We also checked temporal robustness by considering a 2-year time lag ( $\mathrm{t}-2)$ between the dependent and independent variables. The results were consistent with those present here and there were no changes in the direction or significance of the coefficients. We further plotted the data to check for outliers that could be driving the results, and again we failed to find extremely high or low values on arbitrary or pervasive corruption. Moreover, our data does not contain multicollinearity as indicated by individual correlations or the variance inflation factor. Finally, we tested whether there would be significant changes in the coefficients when entering arbitrary and pervasive corruption separately in the equations, but the results continue to reveal a significant coefficient only for the pervasive component of corruption.

\section{DISCUSSION}

In this paper we sought to better understand the relationship between corruption and FDI inflows, complementing extant research. As countries strive to capture a larger share of the FDI flows, namely for the positive effects it may hold on the economy - job creation, knowledge and technology transfer, modernization of the economic structures, fiscal revenues, and so forth - it is critical to comprehend those factors that increase countries' attractiveness for foreign investors.

Our analysis of FDI by 28 home countries in 49 host countries confirmed that host country pervasive corruption is broadly related to decreased FDI inflows. These results follow much of prior research (e.g., WEI, 2000; HABIB; ZURAWICKI, 2002; VOYER; BEAMISH, 2004; CUERVO-CAZURRA, 2006, 2008), but, we did not find an effect for arbitrary corruption in contrast to much prior research (UHLENBRUCK et al., 2006; CUERVOCAZURRA, 2008). The model specification permits us to compute the impact on the FDI inflows of a unit increase in the level of corruption, by inserting in the equation the coefficient of corruption and FDI. For instance, we estimate that a one-unit increase in host country pervasive corruption is related with a decrease of $26 \%$ in the FDI inflows (Exp(-0.305)-1=0.26). That is, corruption pervasiveness reflects a significant increase in the costs of doing business for foreign investors, which is a strong barrier for undertaking FDI.

It is further interesting to notice that the significant negative impact of pervasive corruption may emerge because investors are better able to accurately assess the added costs of doing business. Similarly, the uncertainties involved in arbitrary environments involve many idiosyncratic forms that are hard to measure. The difficulties for firms may arise, for 
instance, on the manners to cope with uncertain, or arbitrary, corruption, which may require different entry modes, such as exports, taking on a partial equity stake in an acquisition or the selection of local partners for joint ventures (see KARHUNEN; LEDYAEVA, 2012; LEE; WENG, 2013; PETROU; THANOS, 2013). Perhaps we failed to find a significant effect for arbitrariness because our investor countries are from OECD countries, and are signatories of international agreements aimed at avoiding or preventing corrupt practices. Nonetheless, given prior research arguing for a more damaging effect of arbitrary corruption over pervasive corruption further attention is warranted. In any instance, it is likely that firms avoid arbitrariness by engaging in alternative entry modes to FDI such as exporting or using collaborative models with host firms such as strategic alliances and joint ventures.

Our results confirm that when either host or home country corruption is low the FDI flows are lower. However, the results also reveal that when both countries have high levels of corruption the FDI seems to increase. In fact, we assessed whether there was an effect of the home country level of corruption and found that not only did high corruption in a home country correlates to a reduction in the FDI to a given host; the negative impact was even larger than that caused by the host country's pervasive corruption. While this may simply be evidence, as suggested by Uhlenbruck et al. (2006), that firms from more corrupt countries, comparatively to other countries, make less foreign investments, it warrants additional research.

Our findings demonstrate that the negative impact of host country pervasive corruption can be alleviated when the investors originate from countries with high levels of corruption. Conceptually this is interesting as it seems to point out to the possibility that firms in more corrupt countries may develop some specific capability of operating amidst corruption and hold know-how on how to deal with it as suggested by Eriksson et al. (1997). This may be a form of home-based corruption-dealing, or corruption-absorbing, capability that render firms of more corrupt countries the ability to operate more effectively in foreign corrupt environments. Future research may deepen this line of inquiry to better understand whether this capability may be broader and encompass the ability to overcome other forms of institutional insufficiencies and explore empirically what truly builds up this capability and its value in international expansion.

\subsection{LIMITATIONS AND FUTURE RESEARCH}

Several limitations of this study are related to the nature of the data. The FDI data used is at the country level, while it would be interesting to capture the effects at the firm level to 
understand how different firms act and, perhaps, detect, industry patterns in manner firms deal with corruption. It is obviously challenging to obtain firm level data and especially in such a sensitive subject as corruption, where firms are unlikely to disclose their practices and managers unlikely to truthfully report their actions. Hence, future research may seek to build a database at the firm-level to examine how firms actually strategize when entering countries with higher levels of corruption. It is worth noting that firms may choose different entry modes when facing host countries with higher levels of corruption. We focused specifically on FDI but alternatives such as some form of partnership do exist. For instance, in countries with high level of arbitrary corruption firms may resort to contractual alliances with host country firms, rather than committing to expensive equity investments.

Our data also does not permit distinguishing foreign investments at the industry level nor the real strategies underlying such investments. Since our data is at the country level we also are not able to examine whether firms entering more corrupt countries seek local firms that may provide host country legitimacy and to some extent buffer against corrupt practices. That is, in a broader perspective, future research may examine how the impact of corruption differs with the nature and industries of the foreign investments.

Finally, it is worth noting that while it would be interesting to add to the model a number of other control variables, there is high correlation among the variables that assess the degree of development of the countries. This seems reasonable since we expect that more developed countries will also have better economic, social, political, and so forth environments that lower the costs of doing business, including those related to corruption of both public officials and private agents.

\section{CONCLUDING REMARKS}

Albeit rather extensive, the research on the impact of corruption on FDI inflows is largely inconclusive and the empirical tests proliferate adding different firm- and countrylevel control variables (JUDGE et al., 2011). Nonetheless, research exploring how much does home country matter have been scant (CUERVO-CAZURRA, 2006, 2008; JUDGE et al., 2011), and our study sheds some empirical evidence that there is a non-trivial home country effect. Albeit in this paper we used a simple dichotomous measure of home country corruption rending a classification for high versus non-high corruption in the home investor country, it is worth noting that we argue that firms may develop in-house some form of corruption-dealing capability. This capability is unlikely to fully develop for low or intermediate levels of home country corruption. Rather firms are more likely to fully develop 
a capability under conditions of high home country corruption. That is, a corruption dealing capability may, at least in part, be seen as location-based.

Additional research will find a large number of possible variables that may be added to empirical models and tested. Longitudinal studies may also be conducted to assess how shifts in the institutional or political environment in a country may impact on FDI. In fact, albeit little explored to date, is also how much FDI impacts corruption (KWOK; TADESSE, 2006) and how firms strategize in face of corrupt environments (ROBERTSON; WATSON, 2004; JENSEN; LI; RAHMAN, 2010; SPENCER; GOMEZ, 2011; KARHUNEN; LEDYAEVA, 2012). Especially relevant may be to enlarge the sample of countries beyond those of OECD and include, for instance countries such as Brazil and China that have become larger recipients of FDI inflows in the past decade. Other empirical tests may simply involve including other control variables such as a control for governance at the country level (perhaps with Kaufman, Kraay, and Mastruzzi's measures at the World Bank) or a public enforcement index (LAPORTA et al., 2006) that provides a transparency measure. Additional controls may include the tax rate of the MNCs in the home and host country that has been shown to drive some FDI (GOODSPEED et al., 2006), and different forms of agreements (trade or other) among countries that would lower the attractiveness of FDI (BROUTHERS et al., 2008).

Future research may consider other mediators. Note that Brouthers, Gao and McNicol (2008) proposed to resolve the debate on the impact of corruption on FDI by theorizing and testing the argument that it is the type of investment - market-seeking or resource-seeking that matters. In this vein, the added cost of corruption could be compensated by market attractiveness for market-seeking FDI but not for resource-seeking FDI. However, they did not actually assess the strategic motivations and rather used the industry to determine whether FDI was market seeking (wholesaling, transportation and financial services, etc.) or resourceseeking (textiles, machinery, etc.). Extensions with other moderators, such as the strategy pursued, may be fruitful research quests.

Understanding the impact of corruption on FDI flows is important for academics, practitioners and public policy makers. For academics there is a contribution to the line of inquiry on the relations between corruption and firms' internationalization through foreign investment. In a similar line, to the research on the effect of institutional environment on the foreign investment behavior of multinational corporations. Nonetheless, the primary implication for theory may be to call for more research on how firms may develop a 
capability to deal with corruption in the host countries - this is likely a form of a political capability (HILLMAN et al., 1999; HOLTBRÜGGE et al., 2007; JIMÉNEZ; DELGADO, 2012). To at least some extent, it seems reasonable to suggest that firms are able to develop home-nurtured political capabilities of dealing with a variety of host institutional inefficiencies.

This study has revealed that is does not suffice to test whether corruption expands or contracts foreign investment flows. It is the characteristics of both home and host countries that jointly affect this relationship. Moreover, the type of corruption - pervasive or arbitrary do seem to matter for FDI (see also CUERVO-CAZURRA, 2008). Hence, future studies need to take into account the type of corruption and perhaps seek to further measure other components of the larger construct that is corruption.

For public policy, this paper highlights the importance of developing a more effective and efficient institutional development, ideally free of corruption. However, it also points that we ought to take into account not only the host corruption but also the home country firms' ability to deal with corruption given the current home environment. Finally, for practitioners, this paper helps in understanding the impact of corruption. It specifically notes that corruption creates added costs and uncertainties in foreign operations that may discourage conducting FDI operations. Nonetheless, it also calls attention to the distinction between the type of corruption that may be found in the foreign markets and their different effects. While, as suggested by Cuervo-Cazurra (2008) corruption arbitrariness may be more damaging, this type of corruption is also far more difficult to assess a priori. It does require additional effort to identify and understand. On the contrary, pervasive corruption is easier to understand and compute in an investment plan.

The scholarly inquiry on how corruption matters for firms is not novel but it also not yet resolved. There has been an upsurge on studies delving into corruption perhaps, at least in part, due to the many economic and financial scandals that have come to disturb the business world. Nonetheless, the type of corruption and what it entails may vary substantially, but it does not suffice to observe only the host country and we showed how FDI flows may be impacted by the investors' country corruption. We advanced the possibility that firms from more corrupt countries may develop a capability of operating amidst a corrupt milieu and not retract from undertaking FDI. In fact, it might be that acting in a corrupt manner may be in the business mind set, or way of doing things, in more corrupt home countries that contribute to reduce firms' sensitivity when entering corrupt host countries. Future research has yet to 
explore further the intricacies involved in how such a capability may develop and how it may be deployed across borders.

\section{ENDNOTES}

${ }^{1}$ The 28 investor countries are Austria, Belgium, Czech. Rep., Denmark, Estonia, Finland, France, Greece, Germany, Hungary, Island, Israel, Italy, Japan, Luxemburg, New Zealand, Netherlands, Poland, Portugal, Slovenia, Slovakia, Spain, USA, Turkey, Switzerland, Sweden, South Korea and United Kingdom .

${ }^{2}$ The 49 host countries are Albania, Armenia, Australia, Austria, Azerbaijan, Belgium, Bulgaria, Byelorussia, Canada, Croatia, Czech Rep., Denmark, Estonia, Finland, France, Georgia, Germany, Greece, Hungary, Ireland, Island, Italy, Japan, Kazakhstan, Kirgizstan, Latonia, Lithuania, Luxemburg, Macedonia, Mexico, Moldova, Netherlands, New Zealand, Norway, Poland, Portugal, Romania, Russia, Slovakia, Slovenia, South Korea, Spain, Sweden, Switzerland, Tajikistan, Turkey, Turkmenistan, Ukraine and Uzbekistan.

${ }^{3}$ http://www.cepii.fr/anglaisgraph/bdd/distances.htm

\section{CONTRIBUTIONS OF AUTHORS}

Manuel Ferreira led the project writing and revising a part of the article.

Helder Carreira - collected data and made initial statistical tests. He wrote a piece of work.

Dan Li - corrected statistical analysis and wrote and reviewed a part of the job.

Fernando Serra - reviewed the work, added literature and participated in the design work.

All authors made multiple revisions and agreed on the final version submitted. There are other specific indications pointing.

\section{REFERENCES}

ABED, G.; DAVOODI, H. Corruption, structural reforms, and economic performance in the transition economies. International Monetary Fund, IMF Working Paper, No. 00/132, Washington, DC, 2000.

AHLSTROM, D.; BRUTON, G. Learning from successful local private firms in China: Establishing legitimacy. Academy of Management Executive, v. 15, n. 4, p. 72-83, 2001.

AIDT, T. Corruption, institutions and economic development. Oxford Review of Economic Policy, v. 25, n.2, p.271-291, 2009.

BARBOPOULOS, L. et al. Foreign direct investment in emerging markets and acquirers' value gains. International Business Review, v. 23, p. 604-619, 2014.

BARDHAN, P. Corruption and development: a review of the issues. Journal of Economic Literature, v. 35, n. 3, p. 1320-1346, 1997.

BÉNASSY-QUÉRÉ, A.; COUPET, M.; MAYER, T. Institutional determinants of foreign direct investment, The World Economy, v. 30, n. 5, p.764-782, 2007. 
BEVAN, A.; ESTRIN, S. The determinants of foreign direct investment into European transition economies, Journal of Comparative Economics, v. 32, p. 775-787, 2004.

BOGMANS, C.; JONG, E. Does corruption discourage international trade? European Journal of Political Economy, v. 27, n. 2, p. 385-398, 2011.

BROUTHERS, L.; GAO, Y.; MCNICOL, J. Corruption and market attractiveness influences on different types of FDI. Strategic Management Journal, v. 29, n. 6, p. 673-680, 2008.

BUSSE, M.; HEFEKER, C. Political risk, institutions and foreign direct investment, European Journal of Political Economy, v. 23, n. 2, p. 397-415, 2007.

CAMPOS, N.; KINOSHITA, Y. Why does FDI go where it goes? New evidence from the transition economies, WP 02/228, IMF Institute, 2003.

COLLINS, J.; UHLENBRUCK, K. How firms respond to government corruption: Insights from India. In: WEAVER, K. (Ed.) Academy of management best paper proceedings. New Orleans: Academy of Management, 2004.

CONTESSI, S. Geographical patterns in the location of FDI: evidence from central European regions. Instituto di Studi Latino-Americani-Bocconi, Working Paper, No. 3-2001, 2001.

CUERVO-CAZURRA, A. Who cares about corruption? Journal of International Business Studies, v. 37, n. 6, p. 807-822, 2006.

CUERVO-CAZURRA, A. Better the devil you don't know: type of corruption and FDI in transition economies. Journal of International Management, v. 14, n. 1, p. 12-27, 2008.

DANIELE, V.; MARANI, U. Do institutions matter for FDI? A comparative analysis of the MENA countries, MPRA, Working Paper, No. 2426, 2006.

DAUDE, C.; STEIN, E. The quality of institutions and foreign direct investment. Economics e Politics, v. 19, n. 3, p. 317-344, 2007.

DELIOS, A.; HENISZ, W. Japanese firm investment strategies in emerging economies. Academy of Management Journal, v. 43, n. 3, p. 305-323, 2000.

DELIOS, A.; HENISZ, W. Political hazards and the sequence of entry by Japanese firms. Journal of International Business Studies, v. 34, n. 3, p. 227-241, 2003.

DOH, J. et al. Coping with corruption in foreign markets. Academy of Management Executive, v. 17, n. 3, p. 114-127, 2003.

EGGER, P.; WINNER, H. Evidence on corruption as an incentive for foreign direct investment. European Journal of Political Economy, v. 21, n. 4, p. 932-952, 2005.

GOODSPEED, T.; MARTINEZ-VAZQUEZ, J.; ZHANG, L. Are other government policies more important than taxation in attracting FDI? Georgia State University, Andrew Young School of Policy Study, Atlanta, 2006.

GROSSE, R.; TREVINO, L. FDI in the US: an analysis by country of origin, Journal of International Business Studies, v. 27, n. 1, p. 139-155, 1996. 
HABIB, M.; ZURAWICKI, L. Corruption and foreign direct investment. Journal of International Business Studies, v. 33, n. 2, p. 291-307, 2002.

HENISZ, W. The institutional environment for multinational investment. Journal of Law, Economics and Organizations, v. 16, n. 2, p. 334-364, 2000.

HERRERA, A.; RODRIGUEZ, P. Bribery and the nature of corruption, Michigan State University, Department of Economics, 2003.

HILLMAN, A.; KEIM, G.; SCHULER, D. Corporate political activity: a review and research agenda. Journal of Management, v.30, n.6, p. 837-857, 2004.

HILLMAN, A.; ZARKHOODY, A.; BIERMAN, L. Corporate political strategies and firm performance: Indications of firm specific benefits from personal service in the US government. Strategic Management Journal, v. 20, n. 1, p. 67-81, 1999.

HOLTBRÜGGE, D.; BERG, N.; PUCK, J. To bribe or to convince? Political stakeholders and political activities in German multinational corporations. International Business Review, v. 16, p. 47-67, 2007.

HUNTINGTON, S. Political order in changing societies, Yale University Press, New Heaven, 1968.

JENSEN, N.; LI, Q.; RAHMAN, A. Understanding corruption and firm responses in crossnational firm-level surveys. Journal of International Business Studies, v. 41, p. 1481-1504, 2010 .

JIMÉNEZ, A.; DELGADO, J. Proactive management of political risk and corporate performance: The case of Spanish multinational enterprises. International Business Review, v. 21, n. 6, p. 1029-1040, 2012.

JIMÉNEZ, A. Does political risk affect the scope of expansion abroad? Evidence from Spanish MNEs. International Business Review, v. 19, n. 6, p. 619-633, 2010.

JOHANSON, J.; VAHLNE, J. The internationalization process of the firm: a model of knowledge development and increasing foreign market commitments. Journal of International Business Studies, v. 8, n. 1, p. 23-32, 1977.

JUDGE, W.; MCNATT, D.; XU, W. The antecedents and effects of national corruption: A meta-analysis. Journal of World Business, v. 46, p. 93-103, 2011.

KARHUNEN, P.; LEDYAEVA, S. Corruption distance, anti-corruption laws and international ownership strategies in Russia. Journal of International Management, v. 18, p. 196-208, 2012.

KINOSHITA, Y.; CAMPOS, N. Estimating the determinants of foreign direct investment inflows: How important are sampling and omitted variable biases? The Bank of Finland Institute for Transition Economies, BOFIT Discussion, Working Paper, No. 10, Helsinki, 2004.

KWOK, C.; TADESSE, S. The MNC as an agent of change for host-country institutions: FDI and corruption. Journal of International Business Studies, v. 37, p. 767-785, 2006. 
LAMBSDORFF, J. How corruption affects persistent capital flows. Economics of Governance, v. 4, n. 3, p. 229-243, 2003.

LEE, S-H.; WENG, D. Does bribery in the home country promote or dampen firm exports? Strategic Management Journal, v. 34, p. 1472-1487, 2013.

LEFF, N. Economic development through bureaucratic corruption. American Behavioral Scientist, v. 8, n. 3, p. 8-14, 1964.

LU, J. Intra- and inter-organizational imitative behaviour: Institutional influences on Japanese firms' entry mode choice. Journal of International Business Studies, v. 33, n. 1, p. 19-37, 2002.

MAURO, P. Corruption and growth. Quarterly Journal of Economics, v. 110, n. 3, p. 681$712,1995$.

MAURO, P. Corruption: causes, consequences and agenda for further research. Finance \& Development, v. 35, n. 1, p. 11-14, 1998.

MEYER, K. Institutions, transaction costs, and entry mode choice in Eastern Europe. Journal of International Business Studies, v. 32, n. 2, p. 357-367, 2001.

NETER. J. et al. Applied linear statistical models. 4. ed. Chicago: Irwin, 1996.

NORTH, D. Institution, institutional change, and economic performance, Cambridge: Cambridge University Press, 1990.

PETROU, A.; THANOS, I. The " grabbing hand" or the "helping hand" view of corruption: Evidence from bank foreign market entries. Journal of World Business, in press, 2013.

ROBERTSON, C.; WATSON, A. Corruption and strategy. Strategic Management Journal, v. 25, n. 4, p. 385-396, 2004.

RODRIGUEZ, P.; UHLENBRUCK, K.; EDEN, L. Government corruption and the entry strategies of multinationals. Academy of Management Review, v. 30, n. 2, p. 383-396, 2005.

ROSE-ACKERMAN, S. Corruption and government: causes, consequences and reform. Cambridge: Cambridge University Press, 1999.

SHLEIFER, A.; VISHNY, R. Corruption. Quarterly Journal of Economics, v. 108, n. 3, p. 599-617, 1993.

SPENCER, J.; GOMEZ, C. MNEs and corruption: the impact of national institutions and subsidiary strategy. Strategic Management Journal, v. 32, n. 3, p. 280-300, 2011.

TANZI, V.; DAVOODI, H. Corruption, public investment and growth. International Monetary Fund, IMF Working Paper, no. 97/139, Washington, DC., 1997.

THORNTON, G. International Business Report. 2011. Disponível em: <www.internationalbusinessreport.com>.

TRANSPARENCY INTERNATIONAL. Annual Report 2003. Berlin, Germany, 2003. 
UHLENBRUCK, K. et al. The impact of corruption on entry strategy: Evidence from telecommunication projects in emerging market. Organization Science, v. 17, n. 3, p. 402414, 2006.

VOYER, P.; BEAMISH, P. The effect of corruption on Japanese foreign direct investment. Journal of Business Ethics, v. 50, n. 3, p. 211-224, 2004.

WEBER, A. Theory of the location of industries. Chicago: The University of Chicago Press, 1929.

WEI, S.-J. Corruption in economic development: beneficial grease, minor annoyance, or major obstacle? World Bank Policy Research, Working Paper, 2048, 1998.

WEI, S-J. How taxing is corruption on international investors? Review of Economics and Statistics, v. 82, n. 1, p. 1-11, 2000.

WERNICK, D.; HAAR, J.; SINGH, S. Do governing institutions affect foreign direct investment inflows? New evidence from emerging economies. International Journal of Economics and Business Research, v. 1, n. 3, p. 317-332, 2009.

WHEELER, D.; MODY, A. International investment location decisions: the case of U.S. firms. Journal of International Economics, v. 33, n. 1-2, p. 57-76, 1992.

WILLIAMSON, O. The economic institutions of capitalism: firms, markets, relational contracting. New York: Free Press, 1985.

WORLD BANK. World development indicators 2009. Washington D.C.: World Bank, 2009.

WORLD ECONOMIC FORUM. Global competitiveness report 2008-2009. 2009.

XU, L.; LI, H.; ZOU, H. Corruption, income distribution, and growth. Economics e Politics, v. 12, n. 2, p. 155-181, 2000. 
APPENDIX

Table 2 - Descriptive Statistics

\begin{tabular}{|c|c|c|c|c|c|c|c|c|c|c|c|c|}
\hline Variables & Mean & $\begin{array}{c}\text { St. } \\
\text { deviation }\end{array}$ & 1 & 2 & 3 & 4 & 5 & 6 & 7 & 8 & 9 & 10 \\
\hline 1. FDI inflows (Ln) & 4.161 & 3.151 & & & & & & & & & & \\
\hline 2. Host country arbitrary corruption & 0.664 & 0.292 & -0.036 & & & & & & & & & \\
\hline 3. Host country pervasive corruption & 2.047 & 1.182 & $-0.235^{* *}$ & $-.060^{*}$ & & & & & & & & \\
\hline $\begin{array}{l}\text { 4. Home country with high } \\
\text { corruption }\end{array}$ & 0.491 & 0.500 & $-0.438^{* *}$ & -0.000 & 0.000 & & & & & & & \\
\hline 5. Host country size & 16.341 & 1.351 & $0.180^{*}$ & $-.064^{*}$ & $.129^{* *}$ & 0.000 & & & & & & \\
\hline 6. Home-host distance & 4.848 & 2.426 & $-0.251^{* *}$ & .032 & $.711^{* *}$ & -0.046 & $-0.139^{* *}$ & & & & & \\
\hline 7. Coastal country & 1.600 & 0.559 & 0.027 & $.101^{* *}$ & $-.183^{* *}$ & $0-.028$ & $0.190^{* *}$ & $-0.156^{* *}$ & & & & \\
\hline 8. Host country bureaucracy & 19.524 & 12.285 & $-0.085^{*}$ & .016 & $.410^{* *}$ & 0.000 & 0.012 & $0.282^{* *}$ & $-0.100^{* *}$ & & & \\
\hline 9. Host country trade restrictions & 82.973 & 7.947 & $0.080^{*}$ & $.093^{* *}$ & $0.454^{* *}$ & 0.000 & $-0.258^{* *}$ & $-.266^{* *}$ & $0.078^{* *}$ & $-0.124^{* *}$ & & \\
\hline 10. Host country inflation & 6.999 & 5.449 & $-0.243^{* *}$ & $-.255^{* *}$ & $0.642^{* *}$ & 0.020 & $-0.057^{*}$ & $0.592^{* *}$ & $-0.227^{* *}$ & $0.209^{* *}$ & $-0.314^{* *}$ & \\
\hline 11. Host restrictions to FDI & 1.817 & 0.723 & $-0.215^{* *}$ & $-.086^{* *}$ & $0.600^{* *}$ & 0.027 & $.069^{*} 0$ & $0.457^{* *}$ & $-0.125^{* *}$ & $0.464^{* *}$ & $-0.560^{* *}$ & $0.572^{* *}$ \\
\hline
\end{tabular}

